\title{
Brown Citrus Aphid Parasitoid, Lipolexis scutellaris Mackauer (Insecta: Hymenoptera: Aphidiidae) ${ }^{1}$
}

Marjorie A. Hoy and Ru Nguyen ${ }^{2}$

\section{Introduction}

The brown citrus aphid, Toxoptera citricida (Kirkaldy), was first detected in Florida in November 1995 in Dade and Broward counties. The brown citrus aphid now has spread throughout the citrus growing region of Florida and could, in future, spread to other citrus-growing regions in the USA.

The brown citrus aphid is a pest of citrus in Asia, apparently preferring citrus species and a few closely-related Rutaceae as hosts. The brown citrus aphid has a relatively simple life history. All individuals are parthenogenetic females, producing live young. A single female thus can initiate a colony, and populations can increase very rapidly. Nymphs mature in six to eight days at temperatures of 20 degrees $\mathrm{C}$ or higher, with a single aphid theoretically able to produce a population of 4,400 within three weeks if natural enemies are absent.

The brown citrus aphid causes economic losses both in groves and nurseries. Adults and nymphs feed on young citrus foliage, depleting the sap. Their feeding can result in leaf curling and shortened terminal branches. They also produce honeydew, which allows sooty mold to grow. More importantly, this aphid is able to transmit citrus tristeza virus more efficiently than other aphid species found on citrus in Florida. Detailed knowledge of the mechanisms by which the brown citrus aphid transmits citrus tristeza virus is lacking. Citrus tristeza virus is a phloemlimited virus with mild and severe strains and is transmitted in a non-persistent manner by the brown citrus aphid, meaning that if the aphid is removed from a virus-infected plant, it can no longer transmit the virus after about 48 hours. Citrus tristeza virus does not multiply in the aphid. Citrus tristeza virus also is transmitted by mechanical inoculation and grafting.

Citrus propagated on sour orange rootstock is especially susceptible to citrus tristeza virus and at least 18 million citrus (especially grapefruit) trees in Florida currently are propagated on such rootstock. Thus, replanting of substantial acreage has begun and will continue during the next few years. In addition, budwood must be maintained free of citrus tristeza

1. This document is EENY-181, one of the Featured Creatures series of the Entomology and Nematology Department, Cooperative Extension Service, Institute of Food and Agricultural Sciences, University of Florida. Published: November 2000. This document is also available on Featured Creatures Website at http://creatures.ifas.ufl.edu. Please visit the EDIS Website at http://edis.ifas.ufl.edu. Additional information on these organisms, including many color photographs, is available at the Entomology and Nematology Department website at http://entnemdept.ifas.ufl.edu/.

2. Marjorie A. Hoy, Entomology and Nematology Department, University of Florida, Gainesville; and Ru Nguyen, Florida Department of Agriculture and Consumer Services, Division of Plant Industry, Gainesville, FL.

The Institute of Food and Agricultural Sciences (IFAS) is an Equal Employment Opportunity - Affirmative Action Employer authorized to provide research, educational information and other services only to individuals and institutions that function without regard to race, creed, color, religion, age, disability, sex, sexual orientation, marital status, national origin, political opinions or affiliations. For information on obtaining other extension publications, contact your county Cooperative Extension Service office. Florida Cooperative Extension Service / Institute of Food and Agricultural Sciences / University of Florida / Larry R. Arrington, Interim Dean 


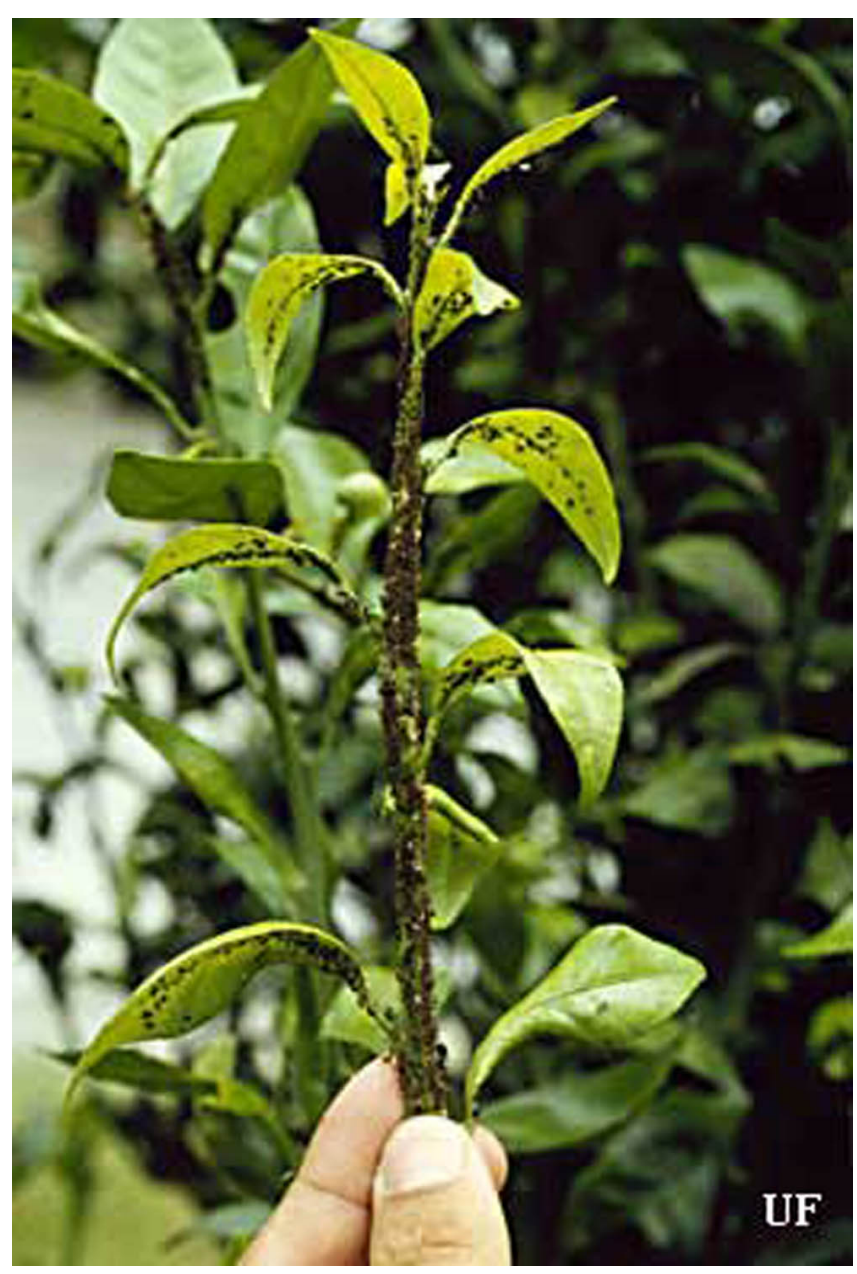

Figure 1. Brown citrus aphids, Toxoptera citricida (Kirkaldy), reproduce rapidly on tender young flush of citrus. Credits: Marjorie A. Hoy, University of Florida

virus because this virus is graft-transmissible. A danger potentially facing Florida's citrus industry is the possibility that the brown citrus aphid will transmit stem-pitting strains of the virus, which are more virulent than the strains that cause citrus 'decline'. Stem pitting strains of citrus tristeza virus can attack and kill trees on rootstock that is tolerant of the milder decline strains. For more information on this virus see:

Citrus Viruses and Viruses-like Diseases

\section{Tristeza}

Florida Citrus Pest Management Guide: Tristeza

By the time the brown citrus aphid was detected in Florida, it had spread through a sufficiently large area of Broward and Dade counties that it was not amenable to eradication efforts.
Natural enemies of the brown citrus aphid already present in Florida include parasitoids, predators, and pathogens-- especially fungi (Michaud 1999). It is likely that native fungi assist in suppressing the brown citrus aphid in Florida during the summer rainy season. Several predators, including ladybird beetles and syrphid fly larvae, and two parasitoid species also attack the brown citrus aphid in Florida, but populations of the brown citrus aphid still can increase dramatically during spring and fall. These population increases could be due, in part, to the fact that the most common parasitoid, Lysiphlebus testaceipes, is relatively ineffective against the brown citrus aphid. Lysiphlebus testaceipes (Cresson) attacks the brown citrus aphid, but rarely develops successfully in it in the field, resulting in the death of both aphid host and parasitoid. Stary (1989) termed this behavior (parasitoid does not complete its development and dies prior to emergence) as 'incomplete parasitization.' Stary (1989) indicated incomplete parasitization could be the result of a new parasitoid-aphid association following movement of either the host or parasitoid into a new area. Often the host aphid species are attacked only when accompanied by the more preferred hosts because the parasitoid cannot produce any progeny on the 'less suitable' host.

Another parasitoid, Aphelinus gossypi Timberlake, which was introduced into Florida from Hong Kong in 1963 for control of spiraea aphid, Aphis spiraecola Patch, has been recovered from the brown citrus aphid, but more commonly attacks other aphid species.

Lysiphlebia japonica Ashmead was introduced into Florida from Japan in 1996 but has not become established (Evans and Stange 1997). Lysiphlebia mirzai Suja-Uddin was imported into Florida from China in 1996 but was not released.

Additional information on the brown citrus aphid can be found at:

Brown Citrus Aphid

Aphid Pests of Citrus 


\section{Classical Biological Control of the Brown Citrus Aphid}

Lipolexis scutellaris Mackauer is able to attack the brown citrus aphid and successfully develop in it. L. scutellaris is widely distributed throughout Asia, where it is known to attack the brown citrus aphid and several other aphid species in citrus. The establishment of L. scutellaris in Florida through a classical biological control program thus has the potential to reduce brown citrus aphid populations in groves and dooryard citrus and may slow transmission of citrus tristeza virus.

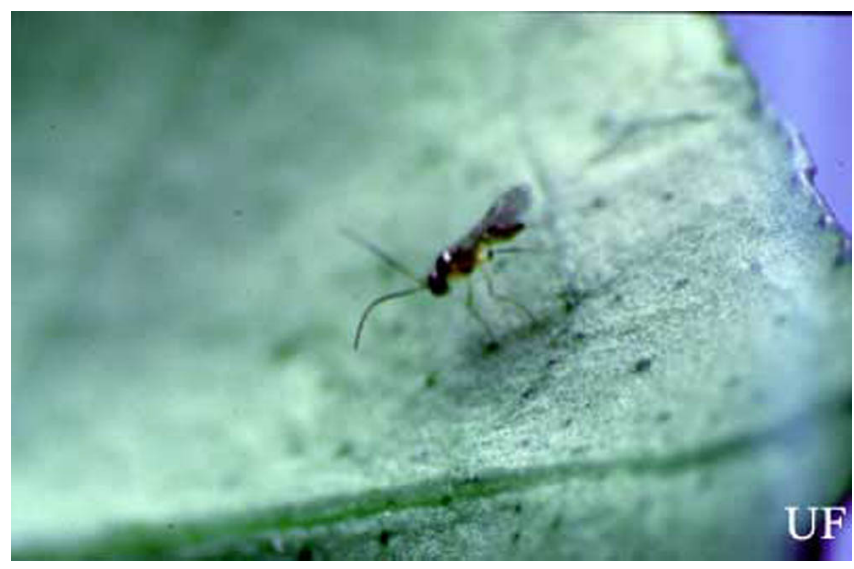

Figure 2. Adult females of Lipolexis scutellaris Mackauer attack immature stages of the brown citrus aphid. This female is seaching for aphids to parasitize. Credits: $\mathrm{Ru}$ Nguyen, Florida Department of Agriculture and Consumer Services, Division of Plant Industry

Only adults of L. scutellaris were imported from Guam into the high security quarantine at the Division of Plant Industry during August 1999 in order to reduce the likelihood that virulent strains of citrus tristeza virus would be imported with aphid hosts (Hoy and Nguyen 2000). A subculture was transferred, with state permission, to the Department of Entomology and Nematology quarantine facility at the University of Florida, Gainesville. The parasitoids were confirmed as L. scutellaris by taxonomic specialist P. Stary, who (Personal communication, May 28, 1999) indicated that the name of this species will be changed soon because "...we have to change this name later for [sic] Lipolexis oregmae (Gahan) because of priority reasons (this is to be suggested in one of our papers on Guam)". However, until the name has been changed formally, we call this parasitoid L. scutellaris (Guam biotype).

\section{Biology of the Aphididae}

Detailed knowledge about the biology of the Guam biotype of $L$. scutellaris has not been published. L. scutellaris belongs to the family Aphidiidae, which consists of approximately 60 genera and subgenera and more than 400 species from around the world (Stary 1988). Lipolexis is one of the most common genera.

The endoparasitic Aphidiidae usually have four larval instars (Stary 1988). Before completing its development, the larva spins a cocoon inside or under the empty aphid exoskeleton. At this stage, the aphid exoskeleton becomes a "mummy." The prepupal, pupal and adult stages develop within the cocoon within the mummy. The adult emergence hole, which is circular, is easily broken. The newly emerged adults need a short time to mature. Males often emerge a bit earlier than females and mating occurs soon, lasting several seconds. Aphidiids typically are arrhenotokous, with mated females producing fertilized (diploid) eggs that develop into females as well as haploid eggs that develop into males and unmated females producing only unfertilized (haploid) eggs that develop into males.

The aphidiid developmental rate is influenced by temperature but usually takes two weeks. Adults are active on warm sunny days, especially in late morning and afternoon, showing a positive phototactic response. Longevity is variable; minimum survival occurs without water and food. The sex ratio in the field typically favors females but is variable due to environmental factors. Oviposition may occur soon after females emerge. Females mate only once, but males can mate several times. Oviposition behavior typically involves antennal tapping of the aphid host, then the female stands on erect legs, bending her abdomen forwards beneath the thorax and between her legs. By moving the abdomen forward, she stings the aphid with her ovipositor. The duration of oviposition ranges from about one second to about one minute. The ovipositing female typically can discriminate between aphids that are previously parasitized, thus avoiding superparasitism (parasitism of the same host by more than one individual). The avoidance of superparasitism is important because only one parasitoid can develop successfully within an immature aphid. 
Host instar preference by the female may vary among species within the Aphidiidae. The reproductive capacity also is variable, with up to several hundreds of eggs per female (Stary 1988). Aphidiids disperse in different ways; adults can disperse by flight or by walking, or immatures can disperse within their live aphid hosts or within mummies. Differences in short- distance dispersal can be found between parasitized live aphids and unparasitized aphids (Stary 1988). Prior to mummification, parasitized aphids typically leave their colony and move to microhabitats that are microclimatically favorable for the parasitoids. Long-distance dispersal of adult parasitoids and parasitized alate aphids occurs by flight (Stary 1988).

The Aphidiidae are parasitoids only of the Aphidoidea (aphids) (Stary 1988). Within the family, some parasitoids are restricted to a single host species (monophagy), to two or more species of the same aphid genus, to two or more genera of the same aphid subfamily, to two or more genera of two or more subfamilies of the same aphid family, or to two or more aphid families (Stary 1988). Host finding starts with the selection of a suitable habitat, with the food plants of the host aphids playing an important role, because the parasitoids seem to be attracted to them (Stary 1988). "The attractiveness of the host aphids to the parasitoids is apparently due to the perception of their kairomones, which seem to be present in honeydew. Host and parasitoid population densities are also important in conditioning the searching activity of the parasitoid" (Stary 1988).

Although parasitism ultimately results in mummification and death, parasitized aphids can develop for some time (Stary 1988). If the first or second instars are parasitized, the aphids do not develop to adults. Aphids parasitized in instar 3 reach the adult stage, producing few or no offspring prior to mummification. Aphids parasitized in instar 4 or as adults do reproduce but to a limited extent. Parasitized aphids consume more food but assimilate it less efficiently. They also gain more weight than unparasitized aphids. Parasitized aphids also produce more honeydew.

Aphidiids are hyperparasitized (when a parasitoid is parasitized by a different wasp species, which results in the death of the primary parasitoid) by Chalcididae, Aphelinidae, Ceraphronidae and Cynipidae (Stary 1988). Hyperparasitoids can reduce the reproductive rate of parasitoids and cannot themselves attack pests such as aphids.

Predators of aphids may not distinguish between parasitized and unparasitized aphids. Fungi are able to infect both parasitized and unparasitized aphids. Ants often attend aphids, yet some aphidiid species can parasitize the ant-attended aphids.

\section{Taxonomic Description of $L$. scutellaris}

Lipolexis scutellaris was described 1962 and revised by Stary and Schlinger (1967). Stary and Schlinger (1967) indicated L. scutellaris was distributed in Hong Kong and Taiwan and apparently did not examine any material from India.

\section{Genetic Variability within $L$. scutellaris}

Stary (1988) indicated that genetic variability within species of aphidiids is substantial, suggesting that some species actually may consist of species complexes. This type of genetic variability could make it inappropriate to compare the biology of $L$. scutellaris from Guam with that of L. scutellaris from India. For example, Stary (1988) pointed out that aphidiids from the same host species but from different areas of the range may differ in developmental rate, host species preference, and adaptation to new climatic conditions. Partial reproductive incompatibility may occur between the different aphidiid populations. Within a defined geographical area, populations on different host species show various genetic diversity patterns. Stary (1988) concluded "It is recommended to classify all parasitoid populations derived from the same host species in a defined area as a parasitoid biotype. A certain number of strains can be distinguished within this biotype."

As a result of this advice, we are calling this population of $L$. scutellaris the 'Guam biotype', even though Dr. Stary suspects it was accidentally introduced into Guam and is not native there (see below). 
L. scutellaris is a koinobiont (a parasitoid that develops inside living, mobile hosts and which benefits from the continued life and feeding of the host). As noted by Godfray (1994), koinobionts have several advantages as natural enemies. Koinobionts can delay their development until the host has matured, which leads to relatively large adult parasitoids that may be "....able to locate more hosts. On the other hand, the specialist adaptations required by exposure to host defenses in endoparasitism result in a narrow host range and tend to reduce the number of hosts encountered. This trend may be offset by the greater host synchronization and specialism that a narrow host range allows..." (Godfray 1994).

\section{Guam Biotype of L. scutellaris}

P. Stary (Personal communication, Oct. 15, 1999) suspects that $L$. scutellaris is "....an accidental immigrant to Guam, presumably from the Philippines as a part of its natural range. The date of its introduction is unknown as there are no earlier data on the aphidiines in Guam."

We obtained adults of L. scutellaris from Guam in August 1999 courtesy of Dr. Ross Miller. L. scutellaris is a primary parasitoid of the brown citrus aphid, but detailed reports on its biology in Guam are lacking. Dr. Ross Miller kindly provided some information about the efficacy of $L$. scutellaris as a parasitoid of the brown citrus aphid in Guam. He noted that:

"Lipolexis scutellaris was likely introduced to Guam from the Asian mainland 15-20 years ago in the form of mummies of citrus aphids on introduced citrus plants. Since then it has established itself as the major aphidiid parasitoid of crop aphids on Guam. Its host range on Guam consists of Toxoptera citricida, Aphis gossypii, Aphis craccivora and Aphis spiraecola. It is most commonly found, and found in the greatest densities, on T. citricida on tangerine, lemon, calamondin, and orange, and A. gossypii on cucumber, eggplant, melon and squash. Both of these aphids are serious aphid pests of Guam, with A. gossypii having the widest host range. Our data show that $L$. scutellaris is specific to aphids on Guam as are other aphidiids. We feel that $L$. scutellaris is an excellent biocontrol agent with moderate dispersal abilities typical of microhymenopterans. We have observed infestation rates as high as $90 \%$ on A. gossypii on cucumber in small ( $<5 \mathrm{ha}$ ) farms. $L$. scutellaris appears to be quite resilient to catastrophic disturbances of its habitat. It was abundant throughout its former range within 6 months of Supertyphoon Paka, which hit Guam in December 1997. It does, however, appear quite susceptible to chemical sprays used on some farmer fields."

Ross Miller (personal communication, May 12, 1999) indicated that parasitoids "...appear most numerous during the rainy season, which extends roughly from July through December", suggesting this biotype/species requires high relative humidities as adults.

In our rearing program in Florida, we found that adults of the Guam biotype required free water for drinking. L. scutellaris kills by attacking the smaller instars of brown citrus aphid. In our laboratory rearing in Florida, the mummies of $L$. scutellaris are found in the soil beneath the citrus trees. None have been found glued to the stems or leaves of these trees. L. scutellaris has a relatively short generation time (12 to 14 days at $75-78 \mathrm{oF}$ ) and both males and females are present, with males typically comprising about $30 \%$ of the progeny. However, males of the Guam biotype appear to develop slightly faster than females because the sex ratio is often skewed to males when the first individuals to emerge in the rearing cages are sampled.

L. scutellaris has been described as an abundant and effective parasitoid of the brown citrus aphid in Guam (R. Miller, personal communication). However, its effectiveness in suppressing brown citrus aphid populations under Florida field conditions will have to be analyzed. Because $L$. scutellaris mummies are found in the soil under the citrus tree when reared in pots in quarantine, it will be interesting to determine whether the imported red fire ant attacks and kills mummies of L. scutellaris in Florida's citrus groves if that behavior is observed in the field. If so, establishment and/or efficacy of $L$. scutellaris could be affected negatively. On the other 
hand, other ant species have been observed defending aphid mummies, which could enhance the likelihood the parasitoid is able to emerge (Stary 1988).

"Reports of direct attack and destruction of mummies by ants are rare and are restricted to some special cases" (Stary 1988). Research to resolve this issue is currently being conducted by Shane Hill in the Department of Entomology and Nematology.

\section{Indian Biotype of $L$. scutellaris}

Singh and Pandey (1997) reported that only mated females of $L$. scutellaris in India oviposit. According to Radhakrishnan and Muraleedharan (1992), when L. scutellaris is reared on Toxoptera aurantii in India, the preoviposition period is 3.1 hours, the oviposition period is two days, the number of eggs laid per female averages 121, the incubation period averages 3.2 days, the duration of larval instars averages 6.9 days, and the pupal period is 5.8 days. Adult females live an average of 5.1 days, while males live only 2.6 days. Radhakrishnan and Muraleedharan (1992) indicated that "Parasitised aphids were generally avoided" by $L$. scutellaris in India and "All the three aphidiid species showed a high degree of discrimination in selecting the specific instar of the host. Mostly, second and rarely third instar nymphs of $T$. aurantii were selected for egg laying." Biswas and Singh (1995) evaluated the number of males and females of $L$. scutellaris in field populations in India. They found that the proportion of males ranged from 29 to $37 \%$.

Dharmadhikari and Ramaseshiah (1970) reported on the biology of $L$. scutellaris in India: $L$. scutellaris "...prefers the host genera, Aphis and Toxoptera." They report the parasitoid's effectiveness was reduced by hyperparasitoids in the genera Alloxysta and Aphidencyrtus. The life cycle from egg to adult emergence was 12.5 days on average during August-September, with mummies starting to appear on the 5th day after oviposition. With the onset of winter, this period was lengthened by three to four days, adults emerging after eight to nine days. Dharmadhikari and Rameseshiah (1970) reported the mummies are "...pale pinkish to brick red with cottony white cocoons appearing through slits in the bodies." Diapausing and non- diapausing mummies were described by Shuja-Uddin (1977).
This description of the Asian biotype mummy is slightly different from what we have seen in our rearing of the Guam biotype of L. scutellaris on the brown citrus aphid. It is possible that this is due to the population in India being reared on a different aphid species (T. aurantii) or to a different biotype of $L$. scutellaris. Dharmadhikari and Ramaseshiah (1970) reported L. scutellaris "...adults lived up to five days in field cages which had been prepared in the laboratory premises. Adults lived one to two days longer when nectar-bearing flowers of Impatiens balsamina were provided in these cages." They further reported that "The females accept almost any stage of the host aphid for oviposition."

\section{Host Range of L. scutellaris}

Information on the host range of $L$. scutellaris is based on taxonomic records of material collected from field samples. There surely are errors in identification of both host aphids and parasitoids, but the data do serve as an indicator of potential host range. L. scutellaris is not known to be a hyperparasitoid.

In India, L. scutellaris is recorded on the following aphid species: Aphis citricola, Aphis craccivora, Aphis fabae, Aphis gossypii, Aphis nerii, Aphis ruborum longisetosus, Aphis solanella, Toxoptera aurantii, Toxoptera odinae (Stary and Ghosh 1983, Ahmad and Singh 1996).

Radhakrishnan and Muraleedharan (1992) reported that L. scutellaris was a parasitoid of Toxoptera aurantii on tea in south India. Singh and Tripathi (1987) recorded L. scutellaris from four aphid species in India: Aphis gossypii, A. craccivora, Myzus avenae, and M. persicae. Singh and Srivastava (1990) reported collecting $L$. scutellaris from the following aphids in India: Aphis citricola, A. craccivora, $A$. fabae, A. gossypii, A. nerii, A. ruborum longisetosus, Trichosiphum formosana, Myzus persicae, Macrosiphum avenae, Rhopalosiphum maidis, $R$. nympheae, Toxoptera aurantii, $T$. citricidus, $T$. odinae, and Tuberolachnus salignus.

In Taiwan, L. scutellaris was reported parasitizing Aphis laburni Kalt. on beans; and parasitizing A. spiraecola, Toxoptera aurantii and $T$. citricidus on Citrus sp. (Chiu and Liu 1969). 
In Vietnam, Stary and Zeleny (1983) reported finding L. scutellaris on Aphis citricola (= brown citrus aphid), Aphis gossypii, A. nerii, and Rhopalosiphum nympheae. They reported the mummies as "...light yellowish to whitish, not directly attached to the leaf. No diapause mummies were found." Stary and Zeleny (1983) reported that L. scutellaris is a widely distributed species in India, Pakistan, southern China, Taiwan, Vietnam, and Japan.

Stary and Zeleny (1983) evaluated published records and host records in Vietnam and concluded that "...Lipolexis scutellaris is a relatively broadly oligophagous species on Aphis, Rhopalosiphum, Toxoptera and other aphids." They further concluded that "Lipolexis scutellaris has a promising host range from the biological control viewpoint: Aphis citricola, Aphis gossypii, Aphis craccivora and others are widely distributed pests in the tropics and more or less also in the other zones."

\section{Potential Effects of L. scutellaris on Rare Endemic Aphids in Florida}

Dr. Susan Halbert, an expert on aphids at the DPI, Florida Department of Agriculture and Consumer Services, discussed whether L. scutellaris "...might attack nontarget aphids and if so, whether the environmental consequences would be serious enough to abandon plans for release [in our classical biological control program]. Any deliberate release of an exotic organism requires thoughtful consideration, but in the end, the decision must be made based on weighing the risks and the benefits".

Dr. Halbert noted that most aphid parasitoids are not particularly specific. Thus, Dr. Halbert addressed two questions: "...are there rare and endangered aphids in Florida that may be impacted, and second, how could this be assessed in the laboratory?" Dr. Halbert indicated there are rare indigenous aphids in Florida, including Aphis minima (Tissot). She concluded, however, that

"In my opinion, exotic aphid parasites are not likely to have much negative effect on Florida's ecosystems. Aphids are obligate plant parasites. Without their host plants, they die. In my opinion, the only way to endanger an aphid species is to endanger its host plant.
Although non- specific aphid parasites may attack native aphids, they are more likely to attack the relatively abundant pests of commercial and ornamental crops. Aphids are the ultimate r-strategists. Many species are capable of a 1000 fold increase in a three-week time period. Populations of aphids fluctuate markedly throughout the year under natural conditions and are unlikely to be affected much by a new parasite unless it selectively attacked them at low density. It is improbable that an exotic general parasite would selectively attack an obscure native aphid at low density."

Dr. Halbert indicated that it would be very difficult to experimentally quantify the risk:

"First, it would be extremely difficult to obtain and culture all the aphid species required, particularly given that some may not be described, and others haven't been seen in 60 years. Others may require plants that are very difficult to obtain and propagate or are too large to contain in quarantine. Second, results are difficult to interpret. If the parasite absolutely refuses a given species, that is a clear cut case, but it is more likely that parasites will complete development in the laboratory on at least some of the test species. Even if this occurs, it is not clear that parasites will parasitize the same aphids in a natural setting."

Finally, Dr. Halbert noted that there is a strong case for classical biological control of the brown citrus aphid:

"Brown citrus aphid is an extremely serious pest of citrus. Its introduction into Florida was a tragedy of major proportions. We expect to lose some $20 \%$ of our citrus trees (about 20 million trees) in the next few years, as a result of the increase [d] spread of decline strains of citrus tristeza virus. Those figures are only for Florida. The aphids inevitably will spread to Texas, Arizona and California, where further major losses will occur." 
Dr. Halbert goes on to conclude that:

"In this case, parasites for brown citrus aphid have the potential to help partially mitigate a major agricultural calamity, and the risks to Florida ecosystems are minimal and impossible to demonstrate. In my opinion, the potential benefits to Florida citrus of introducing parasites of brown citrus aphid outweigh the risks."

\section{Expected Attainable Geographic Range in North America}

Based on our current knowledge of the biology of the Guam biotype of L. scutellaris, its expected geographic range will be where the brown citrus aphid becomes established in citrus. If the brown citrus aphid spreads to other citrus-growing regions in the USA, L. scutellaris could move with the brown citrus aphid into Louisiana, Texas, Arizona, and California if it is sufficiently adaptable to these climates. Because the Guam biotype could have a host range that includes Aphis gossypii, Aphis craccivora and Aphis spiraecola (all of which are on citrus in Florida), the Guam biotype of L. scutellaris could be found where these aphids are found, which could include host plants in addition to citrus.

Because the Guam biotype of $L$. scutellaris is from a tropical/subtropical climate, we do not expect it to colonize temperate regions and it may not tolerate hot, dry summers such as that found in California and Arizona.

\section{Expected Environmental Effects of $L$. scutellaris in Florida}

L. scutellaris is expected to establish on the brown citrus aphid and to reduce brown citrus aphid populations in Florida. The use of pesticides to control this pest could be reduced, leading to fewer negative effects on a variety of natural enemy species in citrus, or negative effects on the ground water, workers, or consumers.

It is unlikely that L. scutellaris would have significant negative effects on beneficial species of insects such as honeybees. No aphids in Florida have been declared to be threatened or endangered. The potential interactions, under Florida conditions, between $L$. scutellaris and any other parasitoids are difficult to predict.

The role of native hyperparasitoids in reducing the effectiveness of L. scutellaris as a natural enemy of brown citrus aphid in Florida remains to be determined. Evans and Stange (1997) reported that Alloxysta megourae complex, Ceraphron sp., Syrphophagus aphidivorus (Mayr) and Pachyneuron aphidis (Bouche) are hyperparasitoids of Lysiphlebus testaceipes Cresson in Florida. L. testaceipes attacks several species of aphids, including the brown citrus aphid in Florida.

\section{Description and Identification of Brown Citrus Aphid Parasitoids in Florida}

Evans and Stange (1997) prepared a key to parasitoids and hyperparasitoids associated with the brown citrus aphid in Florida and included Lipolexis scutellaris in the key because it was expected to be introduced into Florida "...in the near future".

One aphelinid, Aphelinus gossypii Timberlake, was introduced into Florida to control Aphis spiraecola Patch, but can occasionally be found in the brown citrus aphid. L. scutellaris is, however, an aphidiid so would not be confused with A. gossypii. when using the key provided. For example A. gossypii has the antennal flagellum 4-segmented and the fore wing with marginal vein long and stigmal vein short (Evans and Stange 1997). By contrast, the antennal flagellum of the other parasitoids associated with the brown citrus aphid would have the "Antennal flagellum with 8 or more segments, fore wing venation variable, but not as above." (Evans and Stange 1997).

Among the Aphidiidae found attacking the brown citrus aphid in Florida, L. scutellaris can be discriminated from the other two species in the key ( Evans and Stange (1997): adults of L. scutellaris can be separated from Aphidius colemani Vierick by having the fore wing with rm vein absent, radial vein elongate, reaching more than $0.6 \mathrm{X}$ of the length of the disc; and tergite I narrow and parallel-sided; propodeum with 3 distinct areolae in the center (Evans and Stange 1997). 


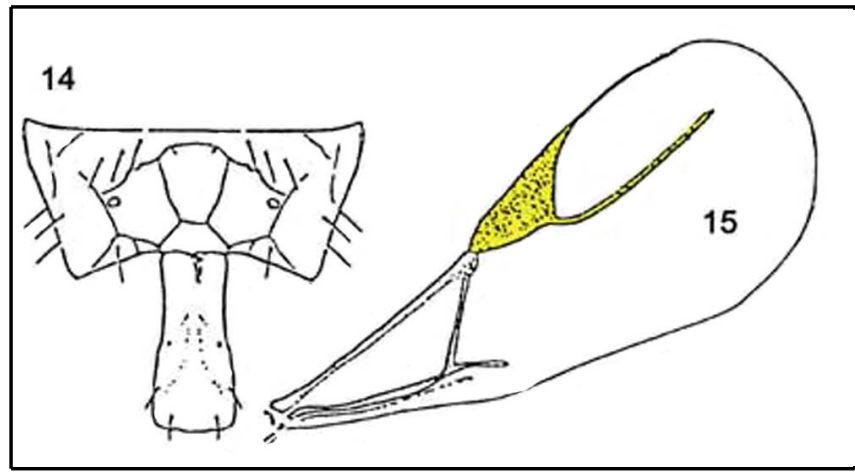

Figure 3. Lipolexis scutellaris forewing (15) and dorsal tergite (14). Note radial vein is long and tergite 1 is narrow and parallel sided. Compare to Aphidius colemani. Credits: Reproduced from Evans and Stange 1997

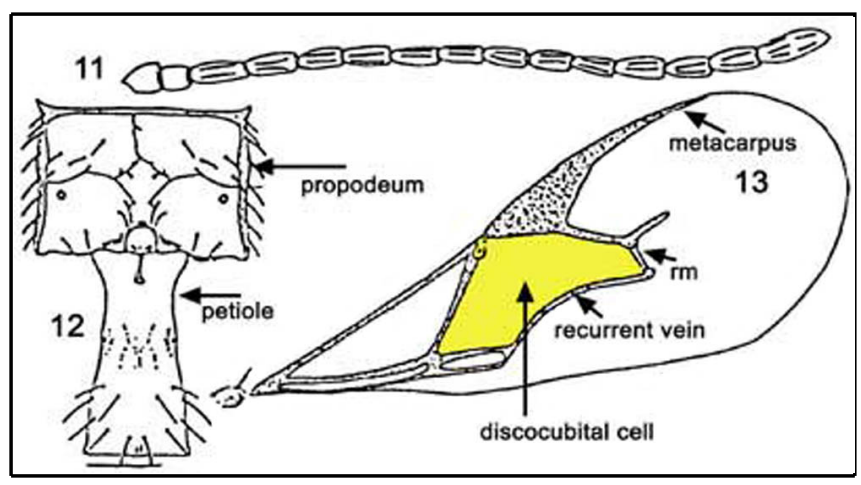

Figure 4. Aphidius colemani forewing (11) and tergite (12). Note that there is an rm and recurrent vein and that tergite 1 is NOT narrow and parallel sided. Credits: Reproduced from Evans and Stange 1997

The second species, Lysiphlebus testaceipes, has a forewing with rm vein present; radial vein reaching 0.5 or less of disc length; propodeum not as in $L$. scutellaris and tergite I shape and sculpture variable.

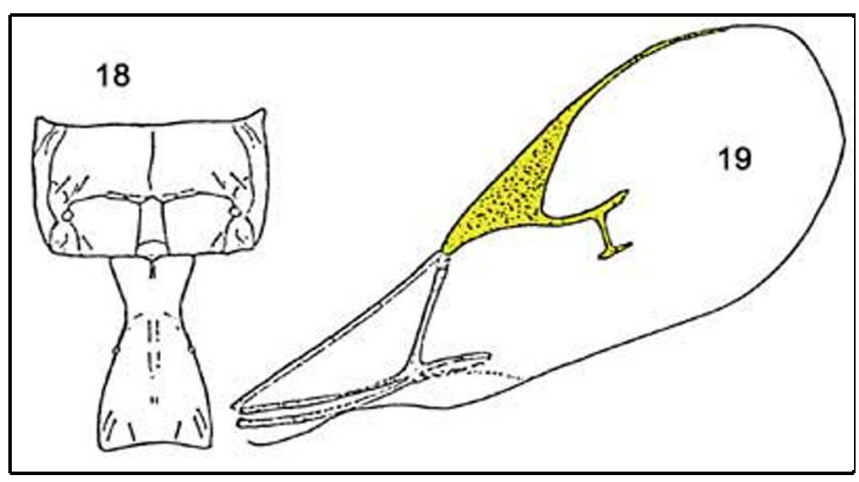

Figure 5. Lysiphlebus testaceipes forewing (19) and tergite 1 (18). Credits: Reproduced from Evans and Stange 1997

The key also discriminates between Lysiphlebia japonica Ashmead and L. mirzai Shuja-Uddin, but $L$. mirzai has not been released in Florida and no recoveries have been made of L. japonica in Florida (Evans and Stange 1997).

\section{Releases of $L$. scutellaris in Florida during 2000}

An application to release $L$. scutellaris was submitted to the Division of Plant Industry, Department of Agriculture and Consumer Services and permission to release $L$. scutellaris was given on June 21, 2000 (Hoy and Nguyen 2000).

The first releases of $L$. scutellaris took place on June 27, 2000 in Gainesville. During the 2000 growing season, L. scutellaris adults were released in citrus groves in Alachua, Indian River, Lake, Marion, Orange, Pasco, Polk, St. Lucie, and Dade counties by Marjorie Hoy, Ru Nguyen and Juan Manuel Alvarez. Additional releases of $L$. scutellaris were made by Phil Stansly and Andrew Chow in Collier and Hendry counties, in Dade county by Jorge Pena and Gwen Myers, in Indian River by Bob Adair, in St. Lucie county by Lee Jones and Ken Hibbard and in Hendry county by Pierre Roberge, Andrew Chow and Phil Stansly. Thus, a total of at least 13,000 L. scutellaris were reared and released between June 27, 2000 and November 2, 2000. Releases generally consisted of 100 to 200 adults per release site.

Recoveries of adult L. scutellaris have been made at several release sites, suggesting that this parasitoid is establishing. The most favorable release sites appear to be where trees of mixed ages are present so that flushes are frequent and continuous, which helps to maintain brown citrus aphid populations in the grove as hosts for the parasitoids. Evidence of successful overwintering during the 2000-2001 winter season will bolster our hopes that L. scutellaris can establish permanently in Florida. The efficacy of L. scutellaris as a natural enemy in Florida's citrus cannot be evaluated until we have evidence that it has permanently established and reached an equilibrium with their aphid hosts.

Samples of $L$. scutellaris have been preserved as voucher specimens both in $70 \%$ (for taxonomic purposes) and in $95 \% \mathrm{EtOH}$ (for future polymerase chain reaction (PCR) tests). The specimens preserved in $95 \% \mathrm{EtOH}$ were frozen at $-80^{\circ} \mathrm{C}$ and stored in the laboratory of Dr. M. A. Hoy. Taxonomic vouchers were deposited at the Florida State Collection of Arthropods, Division of Plant Industry, 
Florida Department of Agriculture and Consumer Services, Gainesville.

\section{Pesticide Selectivity}

No tests have been conducted to determine which pesticides can be used safely without disrupting L. scutellaris populations in citrus groves. However, based on laboratory and field tests conducted in Florida on Ageniaspis citricola, a parasitoid of the citrus leafminer (Phyllocnistis citrella Stainton), oil and copper (Kocide) are IPM-compatible, meaning that $A$. citricola can persist if these products are used for insect, mite and disease control (Villanueva- Jimenez et al. 1998, Villanueva-Jimenez et al. 2000; Villanueva-Jimenez and Hoy 1998).

Other potential IPM-compatible products that will not disrupt establishment and persistence of $L$. scutellaris may include: azadirachtin (Neemix) + $0.4 \%$ oil, and fenoxycarb (Eclipse) $+0.4 \%$ oil.

\section{Selected References}

Ahmad, M.E. and R. Singh. 1996. Records of aphid parasitoids from the north Bihar and associations with their hosts and food plants. J. Adv. Zool. 17: 26-33.

Biswas, S. and R. Singh. 1995. Frequency of constrained sex allocation in field population of aphid parasitoids (Aphidiidae: Hymenoptera). J. Adv. Zool. 16: $16-20$.

Chiu, S.C. and C.S. Liu. 1969. Hymenopterous parasites of citrus tobacco and vegetable aphids in Taiwan. Taiwan Agric. Res. Institute Spec. Publ. 9, Taipei, Taiwan. Dharmadhikari, P.R., and G. Ramaseshiah. 1970. Recent records of aphidiids (Hym.: Aphidiidae in India. Tech. Bull. Commonw. Inst. Biol. Control. 13: 83-89.

Evans, G.A. and L.A. Stange. 1997. Parasitoids associated with the brown citrus aphid, Toxoptera citricida, in Florida (Insecta: Hymenoptera). Entomology Circular 384, Fla. Dept. Agric. Consumer Services, Division of Plant Industry, 5 pages.
Godfray, H.C.J. 1994. Parasitoids. Behavioral and Evolutionary Ecology. Princeton Univ. Press, Princeton, N.J.

Halbert, S.E. and L.G. Brown. 1996. Toxoptera citricida (Kirkaldy), Brown citrus aphidIdentification, biology and management strategies. Fla. Dept. Agric. Consumer Serv., Div. Plant Industry, Entomology Circ. 374: 6 pp.

Halbert, S.E. and L.G. Brown. (October 1996). Toxoptera citricida (Kirkaldy) (Homoptera: Aphididae). UF/IFAS Featured Creatures EENY-007. http://edis.ifas.ufl.edu/IN133 (2 November 2000).

Hoy, M.A. and R. Nguyen. 2000. Classical biological control of brown citrus aphid. Release of Lipolexis scutellaris. Citrus Industry 81: 24-26.

Julien, M.H., and M.W. Griffiths, Eds. 1998. Biological Control of Weeds, A World Catalogue of Agents and their Target Weeds, CABI Publishing, $223 \mathrm{pp}$.

Knapp, J.L., H.W. Browning, R.F. Lee and P.A. Stansly. 1996. The brown citrus aphid. Citrus tristeza virus relationship and management guidelines for Florida citrus. Citrus Industry (March): 12-15.

Komazaki, S. 1994. Ecology of citrus aphids and their importance to virus transmission. JARQ 28: 177-184.

Mackauer, M. 1962. Drei neue Blattlaus-Parasiten aus Hongkong (Hymenoptera: Aphidiidae). Entomophaga 7: 37-45.

Michaud, J.P. 1998. A review of the literature on Toxoptera citricida (Kirkaldy) (Homoptera: Aphididae). Florida Entomologist 81: 37-61.

Michaud., J.P. 1999. Sources of mortality in colonies of brown citrus aphid, Toxoptera citricida. BioControl 44:347-367.

Powell, C.A., R.R. Pelosi and R.C. Bullock. 1997. Natural field spread of mild and severe isolates of citrus tristeza virus in Florida. Plant Disease 81: 18-20. 
Radhakrishnan, B. and N. Muraleedharan. 1992. Bio-ecology of three aphidiid parasitoids of Toxoptera aurantii (Boyer de Fonscolombe) infesting tea in south India. J. Biol. Control 6: 4-8.

Rochapena, M.A., R.F. Lee, R. Lastra, C.L. Niblett, F.M. Ochoacorona, S.M. Garnsey and R.K. Yokomi. 1995. Citrus-tristeza-virus and its aphid vector Toxoptera citricida-Threats to citrus production in the Caribbean and Central and North America. Plant Disease: 79: 437-445.

Shuja-Uddin. 1977. Observations on normal and diapausing cocoons of the genus Lipolexis Foerster (Hymenoptera, Aphidiidae) from India. Bolletino di Laboratorio di Entomol. Agraria "Filippo Silvestri", Portici 34: 51-54.

Singh, R. and S. Pandey. 1997. Offspring sex ratio in Aphidiinae (Hymenoptera: Braconidae): A review and bibliography. J. Aphidol. 11: 61-82.

Singh, R. and P.N. Srivastava. 1990. Host specificity and seasonal distribution of Alloxysta pleuralis, a cynipoid hyperparasitoid of aphids in India. Ecol. Entomol. 15: 215-224.

Singh, R. and R.N. Tripathi. 1987. Records of aphid parasitoids from Terai belt of eastern Uttar Pradesh-I. J. Aphidology 1: 89-92.

Stary, P. 1988. Chapter 9. Natural Enemies. 9.1. Parasites. 9.1.1 Aphidiidae. pp. 171-184. In: Aphids, Their Biology, Natural Enemies and Control. Vol. 2B of World Crop Pests, A.K. Minks and P. Harrewijn, Eds., Elsevier, Amsterdam.

Stary, P. 1989. Incomplete parasitization in aphids and its role in pest management (Hymenoptera: Aphidiidae). Acta Entomol. Bohemoslov. 86: 356-367.

Stary, P. and A.K. Ghosh. 1983. Aphid parasitoids of India and adjacent countries (Hymenoptera: Aphidiidae). Zool. Survey of India, Techn. Monograph 7:1-75.

Stary, P. and E.I. Schlinger. 1967. A revision of the far east Asian Aphidiidae (Hymenoptera). W. Junk, Publ. Den Haag.
Stary, P. and J. Zeleny. 1983. Aphid parasitoids from Vietnam (Hymenoptera: Aphidiidae). Acta Entomol. Bohemoslovaca 80: 190-195.

Taylor, C.E. 1958. The black citrus aphid. Bull. 1953. Minister of Agriculture, Salisbury, Rhodesia.

Tang, Y.Q., S.L. Lapointe, L.G. Brown and W.B. Hunter 1999. Effects of host plant and temperature on the biology of Toxoptera citricida (Homoptera: Aphididae). Environm. Entomol. 28: 895-900.

Villanueva-Jimenez, J.A. and M.A. Hoy. 1998. Toxicity of pesticides to the citrus leafminer and its parasitoid Ageniaspis citricola evaluated to assess their suitability for an IPM program in citrus nurseries. BioControl 43: 357-388.

Villanueva-Jimenez, J.A. and M.A. Hoy and F.S. Davies. 1998. Preliminary IPM program for citrus nurseries. Citrus Industry 79: 34-35, 37-38.

Villanueva-Jimenez, M.A. Hoy and F.S. Davies. 2000. Field evaluation of integrated pest management-compatible pesticides for the citrus leafminer Phyllocnistis citrella (Lepidoptera: Gracillariidae) and its parasitoid Ageniaspis citricola (Hymenoptera: Encyrtidae). J. Econ. Entomol. 93: 357-367.

Whittle, A.M. 1992. Diseases and pests of citrus in Viet Nam. FAO Plant Prot. Bull. 40: 75-81.

Yokomi, R.K., S.M. Garnsey, E.L. Civerolo, and D.J. Gumpf. 1989. Transmission of exotic citrus tristeza virus isolates by a Florida colony of Aphis gossypii. Plant Disease 73: 552-556.

Yokomi, R.K., Y.Q. Tang, L. Nong and M.L. Kok-Yokomi. 1993. Potential mitigation of the threat of the brown citrus aphid, Toxoptera citricida (Kirkaldy), by integrated pest management. Proc. Fla. State Hort. Soc. 106: 81-85.

Yokomi, R.K., R. Lastra, M.B. Stoetzel, V.D. Damsteegt, R.F. Lee, S.M. Garnsey, T.R Gottwald, M.A. Rochapena and C.L. Niblett. 1994.

Establishment of the brown citrus aphid (Homoptera, Aphididae) in Central America and the Caribbean Basin and transmission of citrus tristeza virus. J. Econ. Entomol. 87: 1078-1085. 